tradycji” - jak niezwykle trafnie określiła to za Z. Baumanem w czasie konferencji Agnieszka Stopińska-Pająk - odwrócenie się rodzimego środowiska andragogicznego od historii wychowania, zaczyna stopniowo słabnąć. Warto być może zatem w środowisku Towarzystwa Historii Edukacji rozważyć, czy nie zacieśnić związków instytucjonalnych ze środowiskiem naukowców prowadzących badania w obrębie współczesnej polskiej edukacji dorosłych - np. przez podjęcie wspólnych przedsięwzięć naukowych z odpowiednikiem THE w gremiach andragogicznych, a więc Akademickim Towarzystwem Andragogicznym. Wspólne prace THE i ATA nad „powtórnym zakotwiczeniem” polskiej andragogiki - tym razem już w Baumanowskiej „dobrej tradycji”" mogłyby zapewne przynieść interesujące poznawczo i ważne dla obu środowisk naukowych efekty.

Tomasz Maliszewski

\title{
Seminarium naukowe nt. „Warsztat badawczy współczesnego historyka wychowania" (Obrzycko, 28-29 czerwiec 2010)
}

W dniach 28-29 czerwca 2010 r. w Domu Pracy Twórczej i Wypoczynku w Obrzycku, odbyło się seminarium zorganizowane przez Zakład Historii Wychowania Uniwersytetu im. Adama Mickiewicza w Poznaniu. Jego tematem przewodnim był „Warsztat badawczy współczesnego historyka wychowania”, co spotkało się ze znacznym zainteresowaniem zgromadzonych osób. Byli to nie tylko pracownicy i doktoranci UAM, ale także osoby od wielu lat współpracujące naukowo z Zakładem Historii Wychowania (przede wszystkim z Akademii Pomorskiej w Słupsku, Uniwersytetu Medycznego w Poznaniu, Uniwersytetu Przyrodniczego w Poznaniu, ŁWSH w Żarach, Muzeum Warmii i Mazur w Olsztynie).

Uczestnicy seminarium zostali uroczyście powitani przez kierownika ZHW prof. dra hab. Wiesława Jamrożka oraz prof. dr hab. Dorotę Żołądź-Strzelczyk. W związku z tym, że część uczestników seminarium nie miała okazji wcześniej się poznać, postanowiono, że każdy z obecnych dokona autoprezentacji z uwzględnieniem swoich zainteresowań badawczych.

Kolejnym punktem obrad był wykład inauguracyjny, wygłoszony przez prof. Romana Tomaszewskiego, nt. „Przypis jako zdobnik mitu - uwagi o metodologii badań regionalnych historii wychowania”. Prof. R. Tomaszewski (z Akademii Pomorskiej w Słupsku) przedstawił w nim m.in. zarys rozwoju badań regionalnych, podkreślając, że przez długi czas gromadzono dzięki nim jedynie fakty, co zdaniem tego badacza dzisiaj zasługuje na

${ }_{9}$ Z wystąpienia prof. Agnieszki Stopińskiej-Pająk, Gniezno, 21-06-2010. 
krytykę. Wykład zwieńczony został przedstawieniem postulatów dla badań regionalnych w rozpatrywanym zakresie oraz dyskusją, w której uczestniczyli przede wszystkim dr Edyta Głowacka-Sobiech oraz prof. dr hab. Wiesław Jamrożek.

Po wysłuchaniu wykładu inauguracyjnego zaprezentowana została książka pt. 180 lat Szkoły im. Dąbrówki w Poznaniu (1830-2010), której redaktorami są prof. dr hab. Dorota Żołądź-Strzelczyk oraz dr Justyna Gulczyńska. Dr Justyna Gulczyńska przedstawiła główne informacje historyczne o szkole, omawiając również wcześniejsze publikacje naukowe na ten temat, a także tę najnowszą publikację. W następnej kolejności mgr Tomasz Fetzki (z ŁWSH w Żarach) zaprezentował książkę pt. Aktualność pedagogiki Marii Grzegorzewskiej w kontekście współczesnych wyzwań edukacyjnych, której jest redaktorem. Książka ta stanowi zbiór referatów przygotowanych na konferencję zorganizowaną z okazji jubileuszu 55-lecia utworzenia Zespołu Szkół Specjalnych im. Marii Grzegorzewskiej w Żarach oraz 5-lecia nadania imienia Szkole.

W dalszej części seminarium przyszła kolej na komunikaty uczestników z prowadzonych badań naukowych. Głos zabrała większość zgromadzonych seminarzystów zarówno doktorantów, jak i doktorów oraz samodzielnych pracowników nauki. Ta część seminarium okazała się szczególnie interesująca i w wielu przypadkach przyczyniła się do wszczęcia dyskusji.

Dr Edyta Głowacka-Sobiech oraz mgr Konrad Nowak-Kluczyński podczas spotkania zaprezentowali nowości wydawnicze, głównie z zakresu historii wychowania. Wśród omówionych książek znalazły się m.in. takie pozycje, jak Czesława Kupisiewicza Szkice z dziejów dydaktyki, Joanny Szafran Dla dobra polskiej szkoły. Towarzystwo Nauczycieli Szkót Średnich i Wyższych i jego funkcje społeczno-oświatowe w Drugiej Rzeczypospolitej czy Kamilli Łozowskiej-Marcinkowskiej Sprawy niewieście. Problematyka czasopism kobiecych Drugiej Rzeczypospolitej.

Na zakończenie naukowej części spotkania mgr Piotr Marcinkowski wygłosił referat pt. „Nowe możliwości korzystania z zasobów bibliotecznych”. Referat spotkał się ze szczególnym zainteresowaniem, ponieważ dotyczył codziennej pracy historyków. Mgr Piotr Marcinkowski, jako pracownik Biblioteki Uniwersyteckiej UAM (zastępca dyrektora Biblioteki), przedstawił szereg zagadnień związanych z zasobami tej biblioteki i z korzystaniem z nich, uwzględniając także problem komunikacji pomiędzy pracownikami biblioteki a jej użytkownikami. Dodatkowo omówione zostały polskie normy cytowania w pracach naukowych zasobów internetowych.

Michat Nowicki 